\title{
Schistosomiasis Mansoni in Bananal (State of São Paulo, Brazil). I. Efficiency of Diagnostic and Treatment Procedures
}

\author{
Horacio Manuel Santana Teles/ ${ }^{+}$, Maria Esther de Carvalho*, Cláudio Santos Ferreira**, \\ Fabiana Zacharias*, Valquíria Rosa de Lima, Maria Lucia Condino Fadel***
}

\begin{abstract}
Laboratório de Malacologia *Laboratório de Soroepidemiologia, Coordenação dos Laboratórios de Referência e Desenvolvimento Científico, Superintendência de Controle de Endemias (Sucen), Rua Paula Souza 166, 01027-000 São Paulo, SP, Brasil

**Laboratório de Parasitologia, Instituto de Medicina Tropical, USP, São Paulo, SP, Brasil ***Serviço Regional da Sucen de Taubaté, Taubaté, SP, Brasil
\end{abstract}

Bananal is an important focus of Schistosoma mansoni in the State of São Paulo. Accordingly, programmed active search for human cases, annual coproscopic surveys and treatment of infected cases were started in 1998, aiming at producing a sharp prevalence rate drop by the year 2000.

S. mansoni eggs were searched for in two Kato-Katz slides per patient. Cases were followed up according to the routine of the local Family Health Program.

In 1998, 130 samples out of 3,860 showed S. mansoni eggs; in 1999, 105 out of 3,550, and in 2000, 64 out of 3,528 . Prevalence rates were $3.4 \%, 2.9 \%$, and $1.8 \%$, and average egg-counts 59, 64, and 79 eggs per gram of feces respectively. Prevalence rates decreased steadily after treatment, but persistently positive cases showed no significant decrease in parasite burdens. Egg count variation depended on sex and age bracket.

Persistent residual cases admittedly preclude the eradication of this infection by only searching for and treating carriers. In addition, resistance to therapy and low sensitivity of fecal examinations, can not be ignored. Moderate to heavy worm burdens, frequently associated with hepatomegaly elsewhere, produced no serious cases in Bananal.

Key words: schistosomiasis - control - diagnosis - treatment - resistance - São Paulo - Brazil

The municipality of Bananal is situated in the eastern part of the State of São Paulo, latitude 22 40 '44"S and longitude $44^{\circ} 19^{\prime} 08^{\prime \prime} \mathrm{W}$, at $560 \mathrm{~m}$ above sea level. It has an area of $615 \mathrm{~km}^{2}$. About one half of the estimated 16 thousand inhabitants live in the urban areas. In the year 1975, the discovery of six cases of schistosomiasis mansoni in the municipality was announced by Piza (1976). However, Corrêa et al. (1962) and Ramos and Piza (1971) had already found planorbid vectors in that municipality. Even though the collection of infected snails was at that time a requisite for the transmission of Schistosoma mansoni in a site to be admitted, it is presumable that cases of schistosomiasis in Bananal had been known earlier to the personnel of the Campanha de Combate à Esquistossomose (CACEsq) - Campaign to Combat Schistosomiasis - subsequently known as Superintendência de Controle de Endemias, Sucen (Superintendency of Control of Endemic Diseases).

In a recent paper, Teles (2001) gave an account of the cases diagnosed in Bananal from 1979 onwards, with the aid of stool examinations performed at Sucen laboratories. The author stresses that the transmission of schistosomiasis in the municipality of Bananal is now practically restricted to the urban areas and that the annual rate of notification of new autochthonous cases has varied,

${ }^{+}$Corresponding author. Fax: +55-11-229.8292. E-mail: horacio@sucen.sp.gov.br

Received 18 June 2002

Accepted 15 August 2002 mostly due to reasons only indirectly associated with the implementation of the control program and to a lesser extent to an actual variation in the risks of transmission of the parasite.

There is a broad consensus on the issue of the introduction of S. mansoni into Brazil from Africa alongside the slave traffic, as supported by Lutz (1919), but a controversy persists about the time at which the first foci of S. mansoni were established in Bananal. Machado (1977) was perhaps the author mainly responsible for the diffusion of the idea that, as a result of internal migration, schistosomiasis mansoni spread rather recently across the Brazilian territory towards São Paulo and other Southern states. Piza et al. (1959) hypothesize that $S$. mansoni has possibly reached the valley of the river Paraíba for the first time as a consequence of the arrival of Northeastern Brazilian carriers coming to work. They had taken part in the construction of the Rio-São Paulo highway during the beginning of the third decade of the 20th century, lived in military camps during the Constitutionalist Revolution or done repair works, which lasted until the end of the following decade, on the Estrada de Ferro Central do Brasil (Central Railroad of Brazil). Silva (1983) and Chieffi and Waldman (1988) admit that foci of S. mansoni already existed during the mid 1800 s, before slavery was abolished. At that time, a large slave contingent migrated to São Paulo to work in coffee plantations, the most economically important activity until the mid 1900s. In this context, Silva (1983) suggests that, as the municipality of Bananal remained outside the path of relatively recent migratory pressures, it is likely that schistosomiasis had become endemic earlier in that region than it might be surmised. 
Concerning the intermediate hosts, Teles (1996) reported that besides Biomphalaria straminea, found in one water body, B. tenagophila is mostly responsible for the transmission of $S$. mansoni in Bananal.

In view of the persistence of transmission of schistosomiasis and its detrimental effects upon the health of local inhabitants, a specific plan was devised in 1998, as a result of collaboration between Sucen and local health authorities, to strengthen the actions against schistosomiasis in Bananal. A reduction of its prevalence level to less than $1 \%$ by the year 2000 was among the aims of this plan, which included a parasitological survey, the treatment of infected people, and general prophylactic measures as improvement of water supply and sewer systems. To evaluate the efficacy of such measures and the current chances of development of serious sequels in the long term is the object of this paper.

\section{MATERIALS AND METHODS}

Yearly examination of fecal samples from residents of the urban area of the municipality of Bananal was programmed to detect and eventually treat subjects infected with S. mansoni. The Sucen staff was responsible for the distribution of containers and examination of fecal samples. Work on the field was done in one district at a time, beginning with those with the highest prevalence records.

Microscopic diagnosis of $S$. mansoni was performed by using the quantitative direct examination technique described by Katz et al. (1972), known as the Kato-Katz method. We examined two preparations per stool sample, as recommended by the WHO (1985). The results are given in terms of eggs per gram (epg) of feces. All subjects diagnosed as infected with $S$. mansoni were treated at the local outpatient service with oxamniquine (Mansil ${ }^{\circledR}$ ) not later than 10 days after receipt of results. After treatment, the subjects remained under observation to check any reaction.

\section{RESULTS}

The urban area of the municipality of Bananal, where our work was done, is shown in the Figure. The course of River Bananal within the urban area separates the districts of Niterói, Laranjeiras and Cerâmica, on the lefthand bank and Vila Bom Jardim, Centro and Palha on the opposite bank.

Table I lists numbers of samples examined and proportions of positive cases per year. Until 1997 the periodicity of stool examinations had been irregular. The plan to enhance the activities of prophylaxis and control of schistosomiasis included a more extensive collection of fecal samples.

Table II lists, respectively, the numbers of stool examinations and proportions of positive cases per district and per year during the period from 1994 to 2000.

Table III lists the same data corresponding to the years 1998,1999 and 2000 plus results of egg-counts. Such data suggest that the incidence of this parasitosis was higher in Fazenda Três Barras and Palha in 1998, in Vila Bom Jardim and Laranjeiras in 1999 and in Centro, Bom Jardim and Palha again in 2000. On account of some rather high egg-counts, the occurrence of hepatomegaly can not be ruled out. No evidence of a positive association between prevalence and egg-counts was found. In some cases, low proportions of positives coincided with high eggcounts.

During the three years in which the plan has been in operation, the active search for infected people has significantly increased, the number of examinations performed amounted to $70 \%$ of those performed during the period from 1994 to 2000 and $47 \%$ of new cases diagnosed and treated as shown in Table II. A continuous decrease of the prevalence as a function of time was observed in the districts of Palha, Laranjeiras, Cerâmica and Centro. A steady increase has been observed in the Niteroi district. More than half of the cases diagnosed since 1994 come

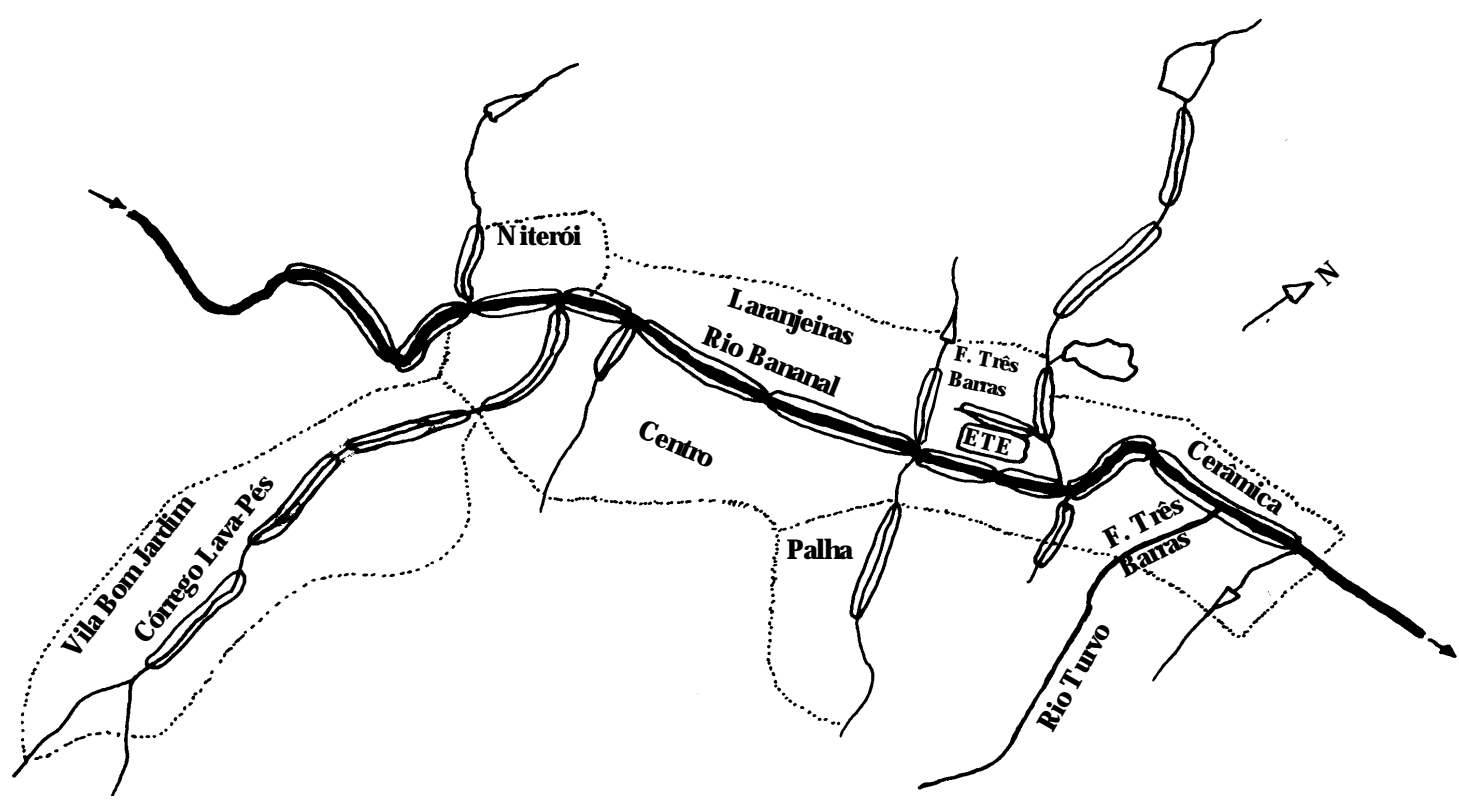

Urban area design of Bananal, State of São Paulo, Brazil. 


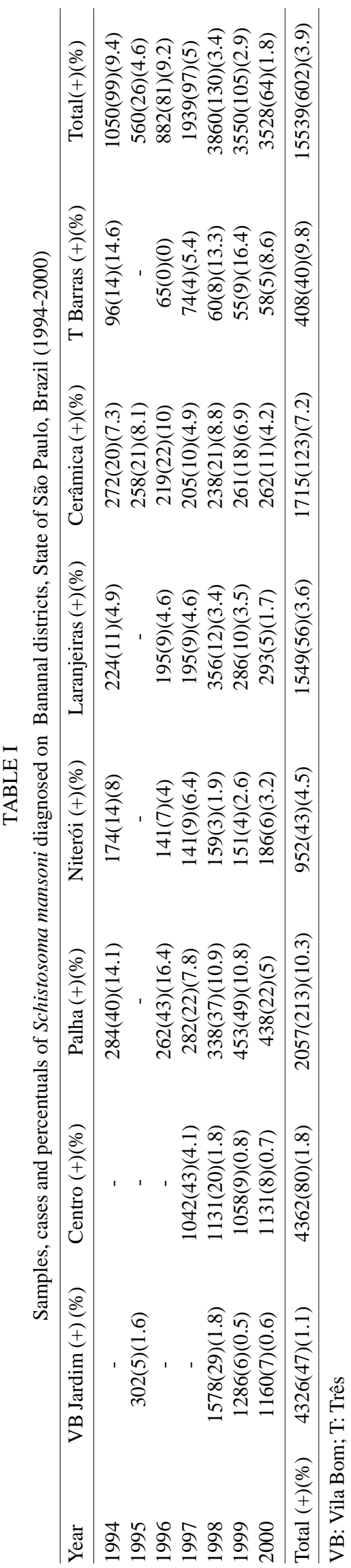

fom a locality known as Fazenda Três Barras and the districts Palha and Cerâmica, where the highest prevalences of the municipality are found.

Distribution of cases by age bracket and sex is shown in Table IV. The highest proportions of positivity and eggcounts were found in male subjects. Females, whose eggcounts had been decreasing, showed a sharp increase in prevalence, while only a slight increase of this was observed in connection with males during the year 2000. Infected males make up about $3 / 4$ of all cases diagnosed between 1998 and 2000. During this period, the male/female proportion remained practically invariable, but average egg-counts are highest in males of all age brackets. Egg-counts less than 100 epg predominate; 13 to $16 \%$ correspond to moderate infections. One case observed in the year 2000 had epg values compatible with serious disease.

Clinical examination revealed no hepatosplenic abnormalities attributable to schistosomiasis. Upon registering at the Programa Saúde da Família (PSF) - Family Health Program, all patients were given oxamniquine (Mansil ${ }^{\circledR}$ ) not later than 10 days after being diagnosed. Inspection of records revealed 7 cases with positive results in 1997 and 1998; 6 in 1998 and 1999; 3 in 1999 and 2000; 2 in 1998 and 2000 .

\section{DISCUSSION}

On inspection, records of the cases entered since 1979 indicate that the transmission of schistosomiasis in Bananal has been stable. Teles (2001) presumes that variations in the number of new cases since then might have been predominantly due to a more extensive use of diagnostic means and only to a lesser degree to a change in the epidemiological picture.

Some discontinuities in the distribution of stool samples examined per district since 1994 are observed, which changed the records of new cases detected. During the late 1980s the program for controlling schistosomiasis was changed by Sucen. From that time onwards, the population samples under study were surveyed with a periodicity which depended on the prevalence observed during the previous year. It is pertinent to the matter under discussion that somewhat earlier in that decade, the fight against vectors of resurgent and emergent diseases, as yellow fever and dengue took priority over the epidemiological vigilance against chronic endemic infections such as schistosomiasis. This tendency resulted in serious operational problems, primarily due to a paucity of financial support. Another drawback to a proper attitude towards the problem of schistosomiasis might be attributed to a misinterpretation of the prophylactic role of chemotherapy and the consequent expectation of a short term extinction of this parasitosis. In view of the complexities peculiar to such an endemic infection, attention has been drawn away from schistosomiasis to other subjects currently in the limelight.

In spite of such obstacles, the prime concern of those involved in organizing programs to control schistosomiasis should include feedback from the effects of previous prophylactic actions and an analysis of the most pertinent variables involved. Conceição and Coura (1978), 
TABLE II

Samples, cases, percentual intensity of infections average (eggs/g of feces) in Bananal districts, State of São Paulo, Brazil (1998-2000)

\begin{tabular}{|c|c|c|c|c|c|c|c|c|c|}
\hline \multirow[t]{2}{*}{ Districts } & \multicolumn{3}{|c|}{1998} & \multicolumn{3}{|c|}{1999} & \multicolumn{3}{|c|}{2000} \\
\hline & Samples & $(+)(\%)$ & epg $a$ & Samples & $(+)(\%)$ & epg ${ }^{a}$ & Samples & $(+)(\%)$ & $\operatorname{epg}^{a}$ \\
\hline Centro & 1,131 & $20(1.8)$ & 76,8 & 1,058 & $9(8.9)$ & 74,7 & 1,131 & $8(0.7)$ & 201,0 \\
\hline Cerâmica & 238 & $21(8.8)$ & 57,7 & 261 & $18(6.9)$ & 42,7 & 262 & $11(4.2)$ & 32,7 \\
\hline Laranjeiras & 356 & $12(3.4)$ & 46,0 & 286 & $10(3.8)$ & 91,2 & 293 & $5(1.7)$ & 69,6 \\
\hline Niterói & 159 & $3(1.9)$ & 20,0 & 151 & $4(2.6)$ & 12,0 & 186 & $6(3.2)$ & 22,0 \\
\hline Palha & 338 & $37(10.9)$ & 94,7 & 453 & $49(10.8)$ & 67,8 & 438 & $22(5)$ & 110,2 \\
\hline VB Jardim & 1,578 & $29(1.8)$ & 33,4 & 1,286 & $6(0.5)$ & 90,0 & 1,160 & $7(0.6)$ & 165,0 \\
\hline T Barras & 60 & $8(13.3)$ & 111,0 & 55 & $9(16.4)$ & 42,7 & 58 & $5(8.6)$ & 36,0 \\
\hline Total & 3,860 & $130(3.4)$ & 62,8 & 3550 & $105(2.9)$ & 60,2 & 3,528 & $64(1.8)$ & 90,9 \\
\hline
\end{tabular}

$a$ : average (eggs/g of feces); VB: Vila Bom; T: Três

Conceição (1978) and Dias et al. (1982) state that the effects of chemotherapy on the reduction of prevalence and parasite burdens vary widely according to local epidemiological peculiarities and that different stages of the action require different strategies.

The information provided by quantitative stool examinations is doubtless epidemiologically pertinent, but some peculiarities of the life cycle of $S$. mansoni adds to the difficulties of microscopic diagnosis, such as the possibility of an infection caused by a small number of worms, possibly all of one sex, irregular oviposition, non-random distribution of the eggs in the fecal mass and development of host immunity (Gryseels 1996). The effects of such factors can be serious when only one fecal sample is collected from each subject. Oxamniquine resistant worms, mentioned by Cioli et al. (1978), Coura et al. (1980), Prata et al. (1980), Bina and Prata (1980), Dias et al. (1982), Kloetzel (1982) and Coelho et al. (1997) also set important limits on the evaluation of prevalence, parasite burden, and risk of infection. All such drawbacks notwithstanding, given the fact that the parasitological surveys were comprehensive, it can be concluded that the prophylactic measures introduced in Bananal succeeded in reducing schistosomiasis prevalence. However, the effect of treatment on parasite burdens was not so evident. The highest percentages of positive cases registered during the last six years $(6.14 \%)$ occurred in districts situated on the left-hand bank of the river Bananal: Niteroi, Laranjeiras, Cerâmica and Três Barras, while the districts Centro, Palha and Bom Jardim contributed 3.8\% of the cases. It is interesting to note that about $65 \%$ of the urban population of Bananal lives in districts situated on the right-hand bank of the same river. It is possible that residents on left-hand bank increase their chance of infection when wading across the river on their way to the center of Bananal. Although the impact of chemotherapy on egg counts has not been immediately evident, a reduction of the number of eggs discharged into water bodies will eventually result. As remarked by MacDonald (1965), a small number of $S$. mansoni eggs discharged into the environment will sustain the transmission of this parasite. That is why the stress on proper sanitation can not be overestimated. Thus in Bananal, the epidemiological situation regarding schistosomiasis has been surveyed yearly.

In Bananal, transmission of schistosomiasis occurs in the absence of recent migratory pressures, under fairly good socio-economic conditions and better than average sanitation. Even in quarters inhabited by low-income families, living standards are higher than those observed on the outskirts of big cities, where Teles (1994) and Coura Filho (1997a,b) observed more favorable conditions for the urbanization of schistosomiasis.

For the moment, in spite of the progress made, it seems prudent to proceed with surveying the population at risk, aiming at diagnosing infection cases and applying chemotherapy to the infected ones. To improve the reliability of diagnostic methods high sensitivity and specificity serological techniques will also be used. High parasite burdens, persistent in spite of a reduction in prevalence, tend to cause a serious disease in which, in addition to intestinal lesions, there is hepatesplenic involvement. To evaluate such cases, careful clinical examinations are mandatory. Unsatisfactory effects of chemotherapy and relapses showed up as a result of parasitological surveys, indicating reinfection or drug-resistance. It is thus advisable, in such cases, to switch to the use of praziquantel, a well-tested drug, and its efficacy being similar to that of oxamniquine.

The distribution of infected people and parasite burdens by sex and age bracket gives further information about the risks of infection and the adequate strategy to control schistosomiasis. There are definite indications that the active search for infected people among the most exposed groups, schoolchildren, for instance, has been adequate. In Bananal, positive cases and the heaviest parasite burdens are found mostly in the 7 to 14 year agebracket. Routine assistance of town dwellers by the Family Health Program solves the problems of clinical diagnosis and follow-up.

As most of the egg counts are at the lower limit of sensitivity of the method (12 epg), a significant proportion of false negative results are expected. Even though a low susceptibility to $S$. mansoni has been attributed to $B$. tenagophila, the characteristics of the foci found in Bananal, of which a low estimated density of the worm population is not the least important, give a clear proof 


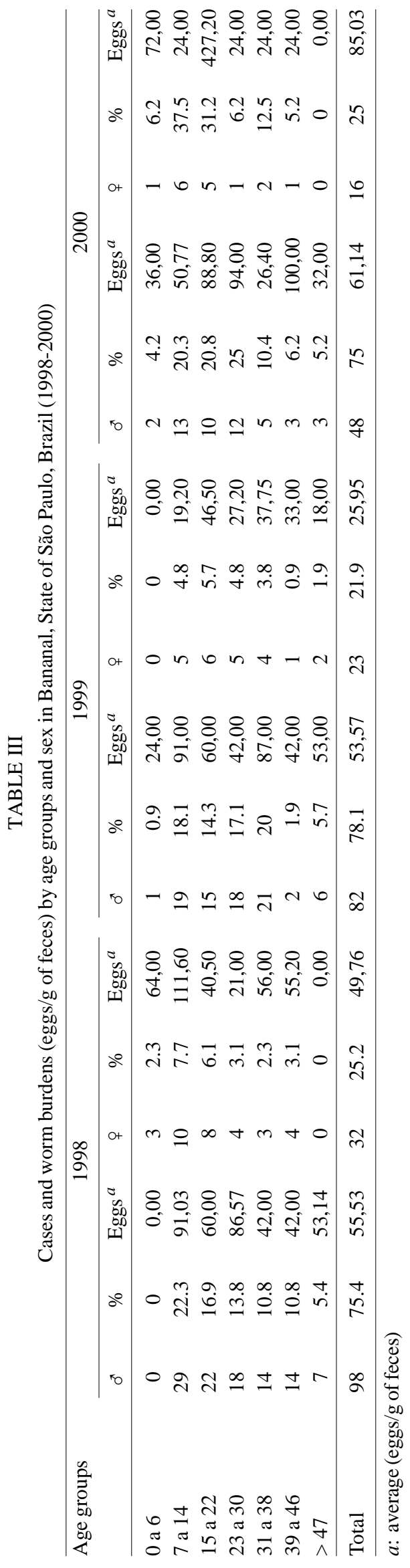

that this vector can keep the levels of transmission above choke off values.

The situation observed in Bananal confirms the views of Conceição and Coura (1978), Katz (1980) and Barbosa and Barbosa (1998), who remark that the probability of success in the control of this endemic infection increases when the peculiarities of each epidemiological situation are taken into account.

Efforts to make sanitation as effective as possible, although recognized as extremely important in preserving the health of a population, produce, as regards the prophylaxis of schistosomiasis, results dependent on the region under consideration. Thus, the impact of sanitation on prevalence differs even in those districts where treated water and adequate sewage disposal are available to most of the inhabitants. For instance, during 1999 and 2000 the districts of Bom Jardim and Palha had already satisfactory sanitation conditions. However, the expected sharp decrease in proportions of positive stools was not observed. The identification of new cases every year indicates a repeated contact of the town inhabitants with contaminated water during activities such as extracting sand and stones from the river bed, washing animals, fishing and some others, which may cause the infection to continue, even if no drug-resistant parasite strain is demonstrated. In fact, only two of the subjects, who might be cases of infection with drug-resistant strains of S. mansoni were observed to pass eggs of this worm after chemotherapy, having denied any further contact with suspect water bodies.

\section{REFERENCES}

Barbosa CS, Barbosa FS 1998. Padrão epidemiológico da esquistossomose em comunidade de pequenos produtores rurais de Pernambuco, Brasil. Cad Saúde Públ 14: 129-137.

Bina JC, Prata A 1980. Oxamniquine no tratamento da esquistossomose em uma população em área de baixa endemicidade. Rev Inst Med Trop São Paulo 22 (Supl. 4): 212-216.

Chieffi PP, Waldman EA 1988. Aspectos particulares do comportamento epidemiológico da esquistossomose mansônica no Estado de São Paulo. Cad Saúde Públ 4: 257275.

Cioli D, Mattoccia LP, Archer S 1989. Resistance of schistosomes to hycanthone and oxamniquine. Mem Inst Oswaldo Cruz 84 (Suppl. I): 38-45.

Coelho PMZ, Silva FCL, Machado JAN 1997. Resistance to oxamniquine of a Schistosoma mansoni strain isolated from patient submitted to repeated treatments. Rev Inst Med Trop São Paulo 39: 101-106.

Conceição MJ 1978. Estudo piloto sobre esquistossomose mansoni em área rural do município de Itanhomi, Vale do Rio Doce, Minas Gerais. Rev Soc Bras Med Trop 12: 81-86.

Conceição MJ, Coura JR 1978. Morbidade da esquistossomose mansoni em uma comunidade rural de Minas Gerais. Rev Soc Bras Med Trop 12: 87-103.

Corrêa R de R, Piza JT, Ramos AS, Camargo LV 1962. Planorbídeos do Estado de São Paulo. Sua relação com a esquistossomose (Pulmonata, Planorbidae). Arq Hig Saúde Públ 27: 139-159.

Coura Filho P 1997a. Distribuição da esquistossomose no espaço urbano. 1. O caso da região metropolitana de Belo Horizonte, Minas Gerais, Brasil. Cad Saúde Públ 13: 245255. 
TABLE IV

Cases distribution by worm burdens (eggs/g of feces) of Bananal districts, State of São Paulo, Brazil (1998-2000)

\begin{tabular}{|c|c|c|c|c|c|c|c|c|c|}
\hline \multirow[t]{2}{*}{ Districts } & \multicolumn{3}{|c|}{1998} & \multicolumn{3}{|c|}{1999} & \multicolumn{3}{|c|}{2000} \\
\hline & $\leq 96$ & $108-864$ & $>864$ & $\leq 96$ & $108-864$ & $>864$ & $\leq 96$ & $108-864$ & $>864$ \\
\hline Centro & 15 & 5 & 0 & 8 & 1 & 0 & 5 & 3 & 0 \\
\hline Cerâmica & 18 & 3 & 0 & 18 & 0 & 0 & 11 & 0 & 0 \\
\hline Niterói & 3 & 0 & 0 & 4 & 0 & 0 & 6 & 0 & 0 \\
\hline Laranjeiras & 12 & 0 & 0 & 8 & 2 & 0 & 4 & 1 & 0 \\
\hline Palha & 29 & 8 & 0 & 41 & 8 & 0 & 19 & 2 & 1 \\
\hline Três Barras & 5 & 3 & 0 & 8 & 1 & 0 & 5 & 0 & 0 \\
\hline VBJardim & 29 & 2 & 0 & 4 & 2 & 0 & 4 & 3 & 0 \\
\hline Total & 109 & 21 & 0 & 91 & 14 & 0 & 54 & 9 & 1 \\
\hline
\end{tabular}

VB: Vila Bom

Coura Filho P 1997b. Distribuição da esquistossomose no espaço urbano. 2. Aproximação teórica sobre a acumulação, concentração, centralização do capital e a produção de doenças. Cad Saúde Públ 13: 415-424.

Coura JR, Argento CA, Conceição MJ, Lewis EM, Santos ML, Magalhães P 1980. Experiências de campo com oxamniquine oral no tratamento da esquistossomose mansoni. Rev Inst Med Trop São Paulo 22 (Supl. 4): 195-202.

Dias LCS, Marçal Junior O, Glasser CM, Kanamura HY, Hotta LH 1992. Control of schistosomiasis mansoni in a low transmission area. Mem Inst Oswaldo Cruz 87 (Suppl. IV): 233239.

Dias LCS, Pedro RJ, Deberaldina ER 1982. Use of praziquantel in patients with Schistosoma mansoni previously treated with oxamniquine and/or hycantone resistance of Schistosoma mansoni to schistosomical agents. Trans $R$ Soc Trop Med Hyg 76: 652-659.

Gryseels B 1996. Uncertainties in the epidemiology and control of schistosomiasis. Am J Trop Med Hyg 55: 103-108.

Katz N 1980. Experiências com a quimioterapia em grande escala no controle da esquistossomose no Brasil. Rev Inst Med Trop São Paulo 22: 40-51.

Katz N, Chaves A, Pellegrino J 1972. Simple divice for quantitative stool thick-smear technique in schistosomiasis mansoni. Rev Inst Med Trop São Paulo 14: 397-400.

Kloetzel K. 1982. Tratamento com praziquantel de portadores de esquistossomose em área endêmica com persistência de positividade após sucessivas administrações de oxamniquine. Rev Inst Med Trop São Paulo 24: 180-187.

Lutz A 1919. O Schistosomum mansoni e a schistosomatose, segundo observações feitas no Brasil. Mem Inst Oswaldo Cruz 11: 121-155.

Machado PA 1977. Programa Especial de Controle de Esquistossomose. O modelo. In Painel Programa Especial de Controle de Esquistossomose, VI Conferência Nacional de Saúde, Ministério da Saúde, Brasil, p. 1-9.

MacDonald G 1965. The dynamics of helminth infections with special reference to schistosomes. Trans R Soc Med Hyg 59: 489-506.

Piza JT 1976. I. Expansão da esquistossomose em São Paulo. II. Medidas adotadas para o seu controle. 28 $\mathrm{a}$ Reunião Anual da Sociedade Brasileira para o Progresso da Ciência, $28^{\circ}$, Brasília (Mimeo.).

Piza JT, Ramos AS, Brandão CSH, Figueiredo CG 1959. A esquistossomose no Vale do Paraíba (Estado de São PauloBrasil). Observações sôbre a doença em de seus municípios e a fauna planorbídica da região. Rev Inst Adolfo Lutz 19: 97-143.

Prata A, Bina JC, Barreto AC, Alecrim MG 1980. Ensaio de controle da transmissão da esquistossomose pela oxamniquina, em uma localidade hiperindêmica. Rev Inst Med Trop São Paulo 22 (Supl. 4): 182-189.

Ramos AS, Piza JT 1971. Sobre os trabalhos da Campanha de Combate à Esquistossomose no Estado de São Paulo, Brasil. Rev Saúde Públ 5: 263-272.

Silva LJ 1983. Sobre a antiguiidade de alguns focos de esquistossomose no Estado de São Paulo. Rev Brasil Malariol 35: 73-78.

Sucen-Superintendência de Controle de Endemias 1982. Situação da Esquistossomose no Estado de São Paulo, Secretaria de Estado da Saúde, São Paulo, 86 pp.

Teles HMS 1989. Distribuição de Biomphalaria tenagophila e B. occidentalis no Estado de São Paulo (Brasil). Rev Saúde Públ 23: 244-253.

Teles HMS 1994. Situação do controle da esquistossomose em São Paulo. Rev Soc Bras Med Trop 27 (Supl. IV): 76-79.

Teles HMS 1996. Distribuição de Biomphalaria straminea ao Sul da Região Neotropical. Rev Saúde Públ 30: 341-349.

Teles HMS 2001. Estudo Parasitológico, da Transmissão e dos Impactos da Profilaxia da Esquistossomose Mansônica no Município de Bananal, Estado de São Paulo, Brasil, Thesis, Instituto de Biologia, Unicamp, Campinas, 73 pp. WHO-World Health Organization 1985. The Control of Schistosomiasis, Technical Report Series, nº. 728, Geneve 99 pp. 